\title{
HIGH PERFORMANCE ANTICORROSIVE EPOXY PAINTS PIGMENTED WITH ZINC MOLYBDENUM PHOSPHATE
}

\author{
PINTURAS EPOXIDICAS ANTICORROSIVAS DE ALTA EFICIENCIA PIGMENTADAS \\ CON FOSFATO DE CINC MODIFICADO CON MOLIBDATO DE CINC
}

\author{
R. Romagnoli ${ }^{1}$, B. del Amo ${ }^{2}$, V. F. Vetere ${ }^{3}$, L. Vèleva ${ }^{4}$
}

\section{SUMMARY}

\begin{abstract}
Zinc molybdenum phosphate belongs to the so called second generation phosphate pigments and is claimed to have equal or greater anticorrosive properties than chromates and better than zinc phosphate alone. Little information is available in the literature about its anticorrosive performance.
\end{abstract}

The aim of this research was to study the anticorrosive performance of zinc molybdemum phosphate in solvent borne epoxy paints employing two anticorrosive pigment loadings. The effect of incorporating zinc oxide as complemetary pigment was also studied.

SAE 1010 steel panels were primed and coated with three different paint systems containing the anticorrosive paint and this paint plus a sealer and/or a topcoat. The anticorrosive efficiency of the different paint systems was assessed by accelerated tests (salt spray, humidity and accelerated weathering). Electrochemical measurements were done employing the anticorrosive paints alone.

Results showed that the highest anticorrosive effect was obtained employing $30 \%$ of zinc molybdemum phosphate. Polarization measurements showed that the anodic film formed on steel blocked the active sites for oxygen reduction. The incorporation of zinc oxide to pigment formula was detrimental due to its high water absorption and to the fact that it reduced zinc molybdemum phosphate solubility by the common ion effect. Polarization curves of pigments mixtures could be used as a guideline to predict the anticorrosive coating performance in accelerated and electrochemical tests. However, the final decision on pigment selection must be taken on the basis of accelerated trials.

Keywords: zinc molybdemum phosphate, epoxy anticorrosive paints, zinc oxide, accelerated tests, electrochemical tests.

\footnotetext{
${ }^{1}$ Miembro de la Carrera del investigador del CONICET; Profesor Adjumto, UNLP

${ }^{2}$ Miembro de la Carrera del Investigador del CONICET

${ }^{3}$ Profesor Timular, UNIP, Jefe Area Estudios Electroquimicos Aplicados a Problemas de Corrosión y Antionrrosión

- Investigador del Centro de investigación y Estudios Avanzados (CINVESTAV), Méxioo
} 


\section{INTRODUCTION}

Zinc molybdenum phosphate belongs to the so called second generation phosphate pigments. It is basically composed by zinc phosphate added with zinc molybdate up to $1 \%$ (expressed as $\mathrm{MoO}_{3}$ ) and is claimed to have equal or greater anticorrosive behaviour than chromates and undoubtely better than zinc phosphate alone [1-6]. The active inhibitive species in this pigment is molybdate anion which is thought to repassivate corrosion pits in steel [7].

Little information is available in the literature about zinc molybdenum phosphate anticorrosive performance. Adrian and Bittner $[3,5,6]$ reported the behaviour of zinc molybdenum phosphate in alkyd paints in comparison with zinc phosphate and zinc chromate. The performance of zinc molybdenum phospahte and other pigments belonging to the second generation phosphate pigments series in compliant primers was also tested [6].

The purpose of the present research was to study the anticorrosive properties of zinc molybdenum phosphate in solvent borne epoxy paints employing two anticorrosive pigment loadings. The effect of incorporating zinc oxide was also studied. Zinc oxide was selected because of its ability to polarize cathodic areas by precipitating sparingly soluble salts [8]. Painted panels with either the anticorrosive paint alone or with a complete paint system were subjected to the salt spray, humidity chamber and accelerated ageing tests. Electrochemical tests were also performed on steel panels coated only with the anticorrosive paint to avoid higher barrier effects due to the complete paint system.

\section{EXPERIMENTAL}

Binder. The film forming material was an epoxy bisphenol polyamide resin.

Pigment. Micronized zinc molybdenum phosphate (average particle diameter $1 \mu \mathrm{m}$ ) was employed as anticorrosive pigment with two different loadings, 10 and $30 \%$ by volume with respect to the total pigment content. The complementary pigments were ferric oxide and barium sulfate and the mixture resulting on partially replacing these pigments $(20 \%$ by volume) by zinc oxide. Ferric oxide was also introduced in the pigment formula because its colloidal particles are said to interact with metallic substrates increasing its coverage [9-11]. Solids contained in the tested anticorrosive paints is shown in Table I.

Table I

Solids in anticorrosive paints compositions ( $\%$ by volume)

\begin{tabular}{|c|c|c|c|c|}
\hline Paint & $\mathbf{1}$ & $\mathbf{2}$ & $\mathbf{3}$ & $\mathbf{4}$ \\
\hline Zinc molybdenum phosphate & 12.1 & 4.1 & 12.1 & 4.1 \\
Ferric oxide & 14.1 & 18.1 & 11.3 & 14.5 \\
Barium sulfate & 14.1 & 18.1 & 11.3 & 14.5 \\
Zinc oxide & ---- & --- & 5.6 & 7.2 \\
Epoxy resin & 59.7 & 59.7 & 59.7 & 59.7 \\
\hline
\end{tabular}

Note: The solven mixure employed for epoxy paimts was toluene/ methyl isobutyl ketone/ butyl aloohol (36/52/12, by weight) 
The inhibitive properties of pigments mixtures were evaluated by means of anodic and cathodic polarization curves. In each case the swept began in the vicinity of corrosion potential at a sweep rate of $3 \mathrm{mV} . \mathrm{s}^{-1}$. The electrolytic cell was composed by an iron electrode (working electrode), a saturated calomel electrode (SCE) as reference and a platinum counterelectrode. The electrolyte was $0.5 \mathrm{M}$ sodium perchlorate solution. Cathodic curves were obtained immediately after the anodic swept.

Paints manufacture and application. It was carried out employing a ball mill with a 3.3 liters jar. The resin solution was added firstly while the pigments were incorporated later; the system was dispersed for 24 hours to achieve an acceptable dispersion degree, grade 4 in Hegman's scale [12].

A sealer and a topcoat, whose composition may be seen in Table $\Pi$, were prepared with a similar method. In the case of the sealer, the non leafing aluminium was incorporated after pigment dispersion to avoid reaction with chlorinated rubber resin.

\section{Table II}

Sealer and topcoat compositions expressed as \% by volume

\begin{tabular}{|c|c|c|}
\hline \multirow{2}{*}{ Components } & \multicolumn{2}{|c|}{ Percentage } \\
\cline { 2 - 3 } & Sealer & Topcoat \\
\hline Ferric oxide & 2.2 & - \\
Barium sulfate & 2.2 & -- \\
Non leafing aluminium & 4.7 & -- \\
Zinc oxide & 0.8 & - \\
Titanium dioxide & -- & 7.3 \\
Alkyd resin (solids) & 5.6 & 20.8 \\
Chlorinated rubber (R10) & 16.8 & 4.8 \\
Chlorinated paraffin (42\%) & 7.2 & 2.1 \\
Pine oil & 0.5 & 0.5 \\
Xilene & 40.0 & 43.0 \\
Aromasol H & 20 & 21.5 \\
\hline
\end{tabular}

Test panels were previously sandblasted to Sa 2 1/2 (SIS 0559 00-67) attaining $20 \pm 4$ $\mu \mathrm{m}$ maximum roughness, degreased with toluene and coated with a wash primer (SSPC-PT 364). Paints applied by means of a spray gun on SAE 1010 steel panels $(15.0 \times 7.5 \times 0.2 \mathrm{~cm})$ and three different paint systems were studied (Table III) to assess their anticorrosive performance.

Salt spray test (ASTM B 117). After 1500 hours exposure panels were evaluated to establish the oxidation degree according to ASTM D 610. In all cases experiences were carried out in triplicate, determining the mean value of the results obtained in the test. Accelerated test were done on panels coated with the anticorrosive paint alone and with different paint systems (Table III). 
Table III

Tested paint systems

\begin{tabular}{|c|c|}
\hline Identification & $\begin{array}{c}\text { Paint systems } \\
\text { (thickness, between brackets) }\end{array}$ \\
\hline 1 & Anticorrosive paint alone $(75 \pm 5 \mu \mathrm{m})$ \\
\hline 2 & $\begin{array}{c}\text { Anticorrosive paint }(40 \pm 5 \mu \mathrm{m}) \\
+\end{array}$ \\
& Sealer $(30 \pm 5 \mu \mathrm{m})$ \\
\hline 3 & $\begin{array}{c}\text { Anticorrosive paint }(40 \pm 5 \mu \mathrm{m}) \\
+ \\
\end{array}$ \\
& Sealer $(30 \pm 5 \mu \mathrm{m})$ \\
& + \\
& Topcoat $(40 \pm 5 \mu \mathrm{m})$ \\
\hline
\end{tabular}

Humidity cabinet test (ASTM D 2247). Panels were placed in the humidity chamber at $38 \pm 1^{\circ} \mathrm{C}$ for 2650 hours. The blistering degree was established according to the ASTM D 714 standard specification.

Accelerated ageing test (ASTM G 26). The accelerated degradation of painted samples was carried out in a Atlas Weather Ometer (Xenon arc type). The test program consisted of a 102 minutes light cycle followed by 18 minutes light water spray cycle. The overall time of each cycle was 2 hours and that of the complete test 1100 hours. The degree of rusting was evaluated according to the above mentioned standard specification.

Corrosion potential measurements. The cells to perform these measurements were constructed by delimiting $3 \mathrm{~cm}^{2}$ circular zones on the painted surface. A cylindrical open acrylic tube, with one flat end, $7 \mathrm{~cm}$ long, was then placed on the specimen and the electrolyte ( $0.5 \mathrm{M}$ sodium perchlorate solution) placed in the tube. The measurements of the corrosion potential of the painted steel substrate with respect to the SCE, were made employing a high impedance voltmeter. Electrochemical tests were carried out on steel panels covered only with anticorrosive paints.

Ionic resistance measurements. The resistance between the steel substrate and a platinum electrode was also measured employing the cells described previously and an ATI Orion, model 170 , conductivity meter which operates at a $1000 \mathrm{~Hz}$ frequency.

Polarization resistance measurements. The polarization resistance of painted specimens was determined as a function of immersion time employing an electrochemical cell with three electrodes. The reference electrode was the SCE and the counterelectrode a platinum grid. The voltage swept was $\pm 10 \mathrm{mV}$, starting from the corrosion potential. Measurements were carried out employing an EG\&G PAR Potentiostat/Galvanostat, Model $273 \mathrm{~A}$ and the software SOFTCORR 352. Polarization resistance of uncoated steel was also monitored as a function of the immersion time. 


\section{RESULTS AND DISCUSSION}

Pigments mixtures. Anodic polarization curves (Fig. 1) reveal that pigments mixtures 1 and 3 (with the highest zinc molybdenum phosphate content) have the best inhibitive properties because they have the lowest passivation current for the second peak. In this sense, the presence of zinc oxide was detrimental because it made difficult to achieve an effective steel passivation (pigment mixture 2). However, zinc oxide restrained the effect of lowering the zinc molybdenum phosphate content (pigment mixture 4). It is thought that the passive film formed by corrosion is similar to that formed at potentials previous to the second peak (which corresponds to the oxidation of ferrous species to ferric ones); in the case of mixtures 1 and 3 a more protective film seemed to be formed because, as it was said before, the current corresponding to the second peak decreased notably.

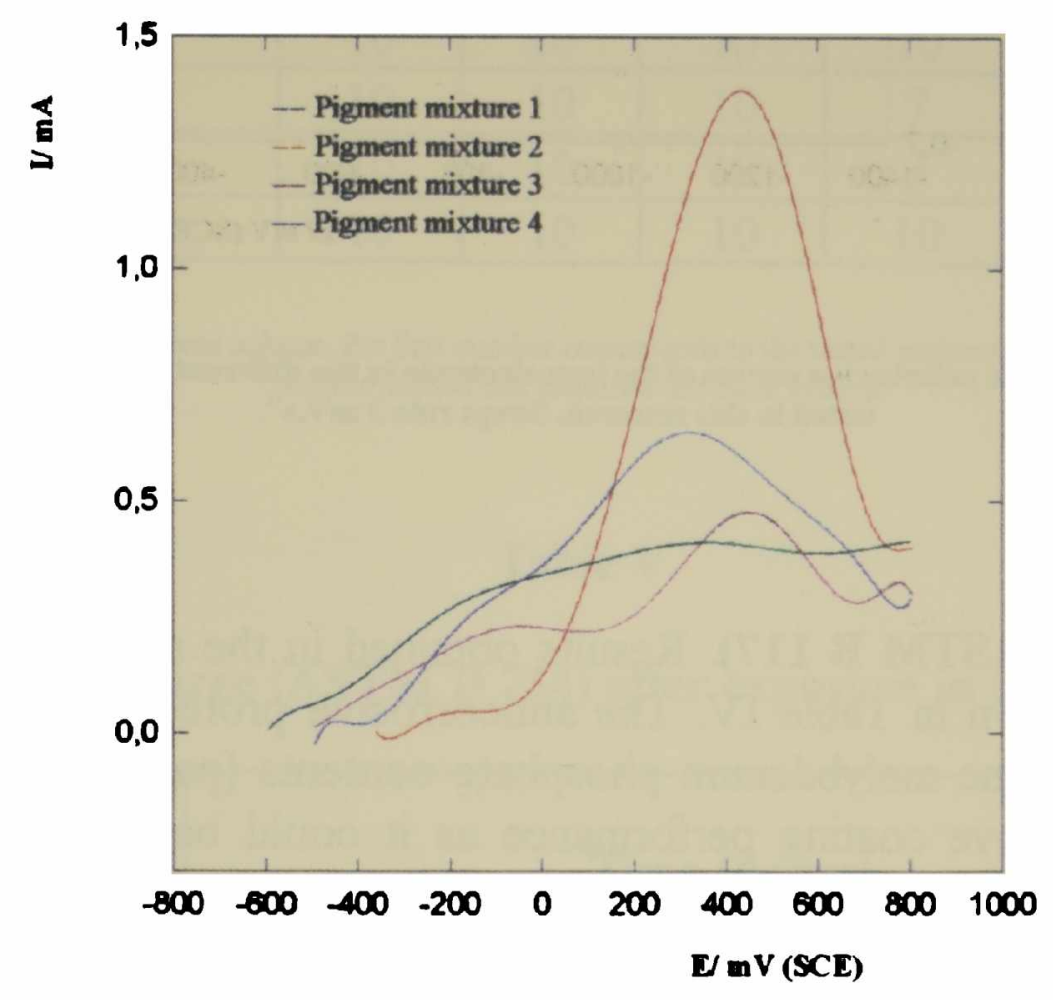

Fig.1.- Anodic polarization curves of the iron electrode in the different pigment mirtures tested. Swept rate $3 \mathrm{mV} \mathrm{s}^{-1}$.

From the cathodic polarization curves (Fig. 2), it may be seen that the higher the zinc molybdenum phosphate content in the pigment mixture the lower the oxygen diffusion current is. The presence of zinc oxide in mixture 3 resulted detrimental because it increased the oxygen diffusion current. It must be remembered that the highest the oxygen diffusion current the higher the corrosion rate would result.

As the cathodic curve was obtained after performing the anodic one, it was concluded that the film formed on the electrode during the anodic scan blocked the actives sites for oxygen reduction.

According to the foregoing discussion, it may be expected that paints formulated with the pigment mixture 1 must show the best anticorrosive performance and paints incorporating mixtures 2 and 4 the worst one. 


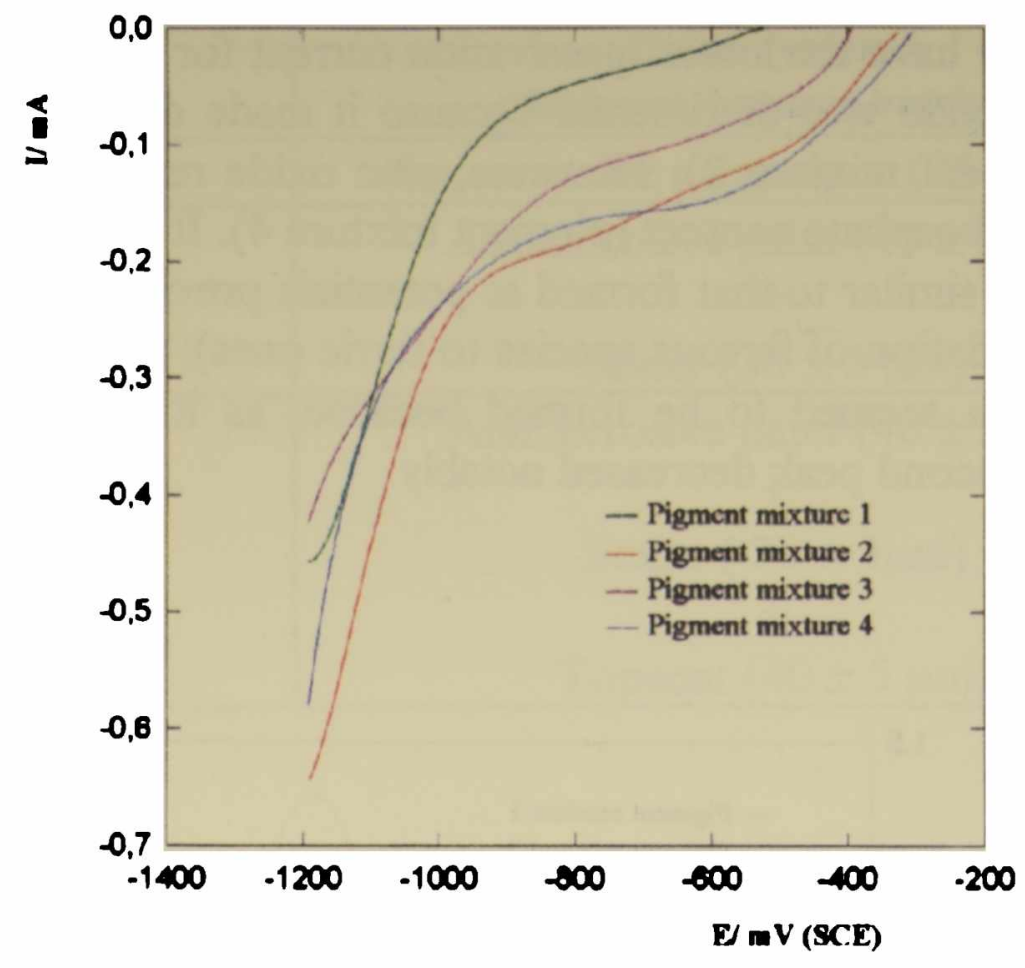

Fig 2.- Cathodic polarization curves of the iron electrode in the different pigment mixtures tested in this research. Swept rate $3 \mathrm{mVs}^{-1}$.

Salt spray test (ASTM B 117). Results obtained in the salt spray cabinet after 1500 hours of testing are shown in Table IV. The anticorrosive protection was more efficient for paints with the highest zinc molybdenum phosphate contents (paint 1). The incorporation of zinc oxide did not improve coating performance as it could be expected from data in the literature [12] and previous results obtained with alkyd paints [13]. This is due to the fact that zinc oxide has a relatively high water absorption [14] and that it reduces zinc molybdenum phosphate solubility by the common ion effect. Evidently, these characteristics prevailed over the catodic protection provided by this pigment.

Paint system 2 (anticorrosive paint+sealer) proved to be as efficient as system 1 (two coats of the anticorrosive paint); this may be attributed to initial high barrier effect developed for anticorrosive paints as it will be said later. The presence of a topcoat (Paint system 3) enhanced the barrier effect and all systems showed high effciency including those containing zinc oxide. Results were confirmed after paint system removal.

Humidity cabinet test (ASTM D 2247). Paints blistering results are presented in Table V. Paint with the higher anticorrosive pigment content ( paint 1, Table I) did not present blistering after 2640 hours exposition . Blistering increased as the zinc oxide content did. It was not observed signs of corrosion under the blisters except for paint 4.3 after 1500 hours (Table IV and V). In all cases the blistering was higher in system 3 but blisters originated between at the anticorrosive sealer paint interfase. 
Table IV

Rusting degree (ASTM D 610) after exposure in the salt spray test

\begin{tabular}{|c|c|c|c|c|c|}
\hline \multirow{2}{*}{$\begin{array}{c}\text { Paint } \\
\text { systems }\end{array}$} & \multicolumn{5}{|c|}{ Time (hours) } \\
\cline { 2 - 6 } & $\mathbf{3 6 0}$ & $\mathbf{7 2 0}$ & $\mathbf{9 6 0}$ & $\mathbf{1 3 0 0}$ & $\mathbf{1 5 0 0}$ \\
\hline 1.1 & 10 & 10 & 10 & 9 & 8 \\
\hline 1.2 & 10 & 10 & 10 & 10 & 9 \\
\hline 1.3 & 10 & 10 & 10 & 10 & 10 \\
\hline 2.1 & 10 & 10 & 10 & 8 & 7 \\
\hline 2.2 & 10 & 10 & 9 & 8 & 6 \\
\hline 2.3 & 10 & 10 & 10 & 10 & 10 \\
\hline 3.1 & 10 & 10 & 10 & 8 & 6 \\
\hline 3.2 & 10 & 10 & 10 & 9 & 7 \\
\hline 3.3 & 10 & 10 & 10 & 10 & 10 \\
\hline 4.1 & 10 & 10 & 10 & 7 & 6 \\
\hline 4.2 & 10 & 10 & 10 & 7 & 6 \\
\hline 4.3 & 10 & 10 & 10 & 10 & 8 \\
\hline
\end{tabular}

Note. In the paint system column, the first number corresponds to the tested anticorrosive paint (Table 1) and the second one identifies the paint system.

Table V

Blistering degree (ASTM D 714) after exposure in humidity test

\begin{tabular}{|c|c|c|c|c|c|c|}
\hline \multirow{2}{*}{$\begin{array}{c}\text { Paint } \\
\text { Systems }\end{array}$} & \multicolumn{7}{|c|}{ Time (hours) } \\
\cline { 2 - 7 } & $\mathbf{3 6 0}$ & $\mathbf{7 2 0}$ & $\mathbf{9 6 0}$ & $\mathbf{1 5 0 0}$ & $\mathbf{1 8 7 2}$ & $\mathbf{2 6 4 0}$ \\
\hline 1.1 & 10 & 10 & 10 & 10 & 10 & 10 \\
\hline 1.2 & 10 & 10 & 10 & $8 \mathrm{~F}$ & $8 \mathrm{~F}$ & $8 \mathrm{~F}$ \\
\hline 1.3 & $10 \mathrm{~F}$ & $8 \mathrm{~F}$ & $8 \mathrm{~F}$ & $8 \mathrm{~F}$ & $8 \mathrm{~F}$ & $8 \mathrm{~F}$ \\
\hline 2.1 & $8 \mathrm{~F}$ & $8 \mathrm{M}$ & $8 \mathrm{M}$ & $8 \mathrm{M}$ & $8 \mathrm{M}$ & $8 \mathrm{M}$ \\
\hline 2.2 & $6 \mathrm{~F}$ & $6 \mathrm{~F}$ & $6 \mathrm{M}$ & $6 \mathrm{M}$ & $4 \mathrm{MD}$ & $4 \mathrm{MD}$ \\
\hline 2.3 & $4 \mathrm{~F}$ & $4 \mathrm{MD}$ & $4 \mathrm{D}$ & $4 \mathrm{D}$ & $4 \mathrm{D}$ & $4 \mathrm{D}$ \\
\hline 3.1 & $8 \mathrm{~F}$ & $8 \mathrm{~F}$ & $8 \mathrm{~F}$ & $8 \mathrm{~F}$ & $8 \mathrm{~F}$ & $8 \mathrm{~F}$ \\
\hline 3.2 & $8 \mathrm{~F}$ & $8 \mathrm{MD}$ & $8 \mathrm{MD}$ & $8 \mathrm{D}$ & $6 \mathrm{~F}$ & $6 \mathrm{~F}$ \\
\hline 3.3 & $6 \mathrm{~F}$ & $6 \mathrm{~F}$ & $6 \mathrm{~F}$ & $6 \mathrm{~F}$ & $6 \mathrm{~F}$ & $6 \mathrm{~F}$ \\
\hline 4.1 & $8 \mathrm{~F}$ & $8 \mathrm{MD}$ & $8 \mathrm{MD}$ & $8 \mathrm{MD}$ & $8 \mathrm{MD}$ & $8 \mathrm{MD}$ \\
\hline 4.2 & $8 \mathrm{~F}$ & $8 \mathrm{D}$ & $8 \mathrm{D}$ & $6 \mathrm{~F}$ & $6 \mathrm{~F}$ & $6 \mathrm{~F}$ \\
\hline 4.3 & $6 \mathrm{~F}$ & $6 \mathrm{MD}$ & $6 \mathrm{MD}$ & $6 \mathrm{MD}$ & $6 \mathrm{MD}$ & $6 \mathrm{MD}$ \\
\hline
\end{tabular}

Note: The numeral represents blister size: 10 no blistering 8 the smallest size blister, etc Letlers indicate the frequency: $\mathrm{D}$, dense, $\mathrm{MD}$, medium dense, $\mathrm{M}$, medium; F few.

Accelerated ageing test (ASTM G 26). All paints exhibited a good behaviour after 1100 hours exposure. No signs of corrosion were observed neither on the painted surface nor 
on the steel substrate. Blistering was, as a general rule, low and increased slightly for paints containing zinc oxide. It may be expected that these paint systems would perform acceptably in outdoor exposure for at least three years without showing signs of corrosion because, as it was stated in the literature, because 1100 hours of accelerated wheathering may be considered, as an average, equivalent to 3 years outdoor exposure [15].

Corrosion potential measurements. The best anticorrosive protection was afforded by paints 1 and 3 and the high barrier effect showed by these paints made it impossible to measure accurately the painted panel potential. As it was predicted by polarization curves obtained with the iron electrode dipped into the different pigment suspensions, the diminishing of zinc molybdenum phosphate content impaired the paint performance (paint 2) as well as the incorporation of zinc oxide. In both cases corrosion potential of painted panels derived towards negative values during the test period (Fig. 3).

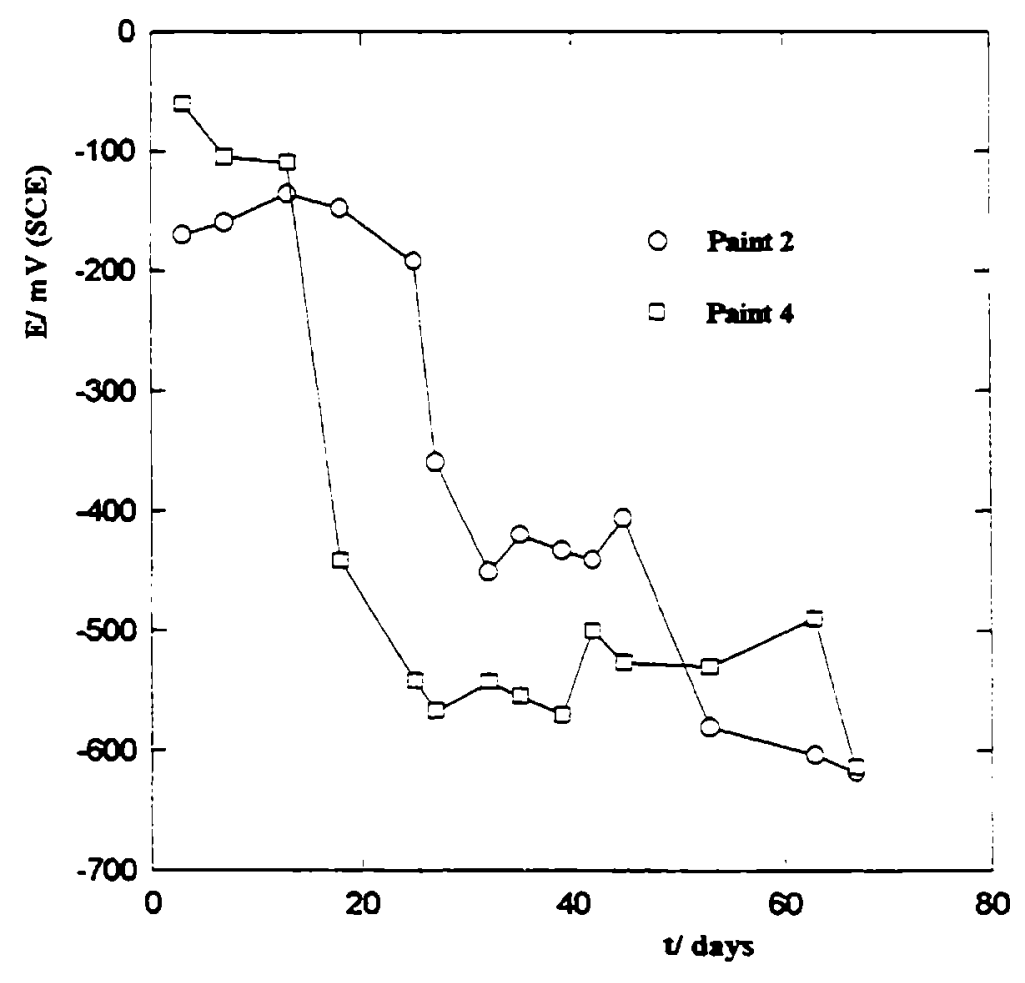

Fig. 3.- Corrosion potential of painted sted panels as a function of the exposure time, in $0.5 \mathrm{M}$ sodium perchlorate solution.

Ionic resistance measurements. The measured resistance is composed by two contributions: the solution resistance and the paint film resistance. As the solution resistance is low $(84 \Omega)$ the paint film resistance is responsible of the measured values. Polarization effects may be neglected at the measuring frequency employed in this test.

The ionic resistance of paints 1 and 3 was higher than $10^{8}$ and $10^{7} \Omega \cdot \mathrm{cm}^{-2}$ respectively, giving full protection to the steel substrate by barrier effect. Paints 2 and 4 showed high ionic resistance at the beginning of the test but this barrier effect was lost as time elapsed (Fig.4). The more impervious films corresponded to the highest anticorrosive pigment content; this led to think that pigment-binder interaction is responsible for higher barrier effect of paints 1 and 3 . In the case of paint 3 this was slightly impaired by the presence of zinc oxide in the film, turning it more susceptible to electrolyte penetration. 


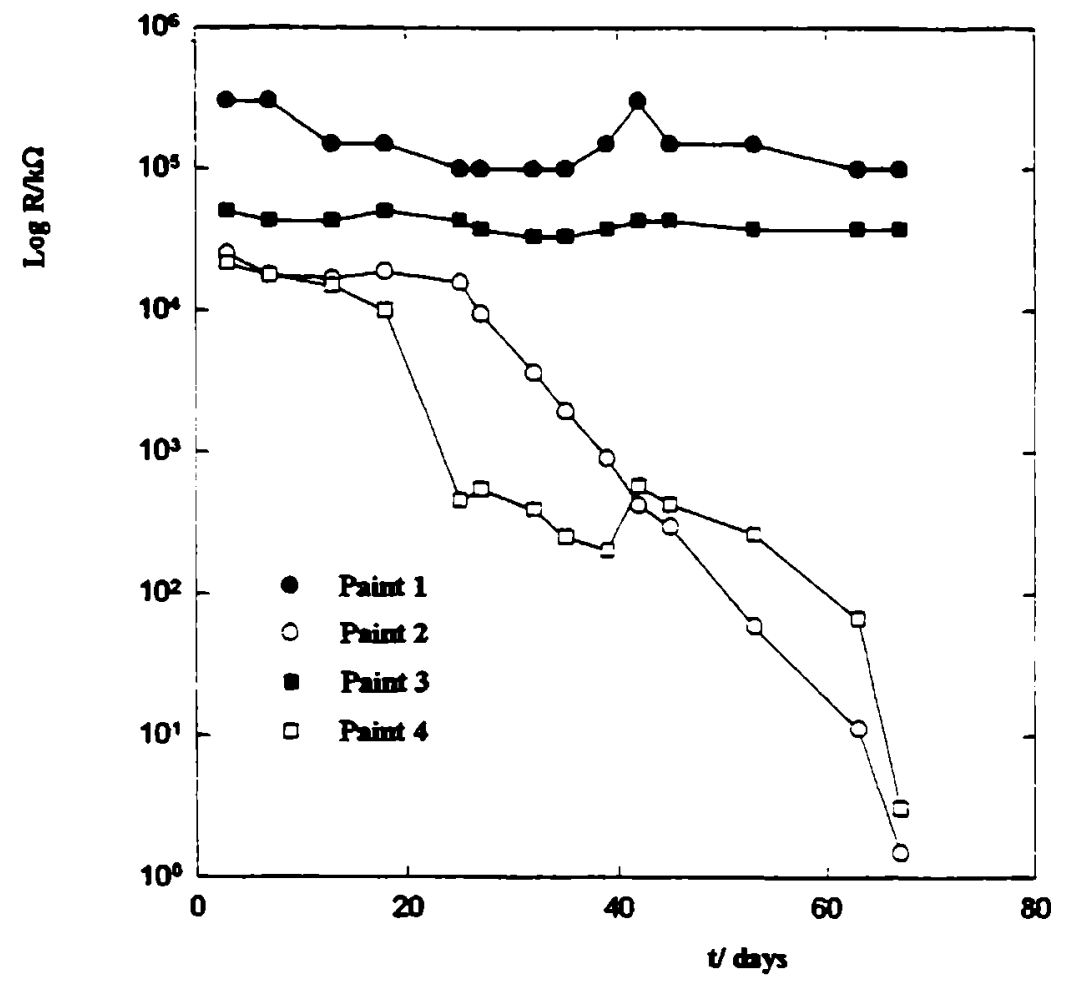

Fig. 4.- Resistance of painted steel as a function of the exposure time in $0.5 \mathrm{M}$ sodium perclorate solution.

Polarization resistance measurements. The high barrier effect showed by paints 1 and 3 controlled paint behaviour. In these cases a linear response is to be obtained and it makes no sense to measure the variation of polarization resistance as a function of time. However, once paints 2 and 4 lost part of their barrier properties polarization resistance was measured and it was found that it exceeded the ionic resistance indicating that zinc molybdenum phosphate inhibited steel corrosion [16].

\section{CONCLUSIONS}

1. The obtained results showed that the highest anticorrosive effect is obtained employing $30 \%$ by volume of zinc molybdenum phosphate in the pigment composition. Polarization measurements show that the anodic film formed on steel blocked the active sites for oxygen reduction.

2. The ferric oxide and barium sulfate employed as extenders gave an additional barrier effect.

3. Zinc oxide is not recommended in epoxy paints pigmented with zinc molybdenum phosphate. This may be due to its high water absorption and to the fact that it reduces zinc molybdenum phosphate solubility by the common ion effect.

4. Polarization curves of pigments mixtures may be used as a guideline to predict the probable anticorrosive coating performance in accelerated and electrochemical tests. However, the final decision on pigment selection must be taken on the basis of accelerated trials. 


\section{AGKNOWLEDGEMENTS}

The authors are grateful to CONICET (Consejo Nacional de Investigaciones Científicas y Técnicas ), CIC (Comisión de Investigaciones Científicas de la Provincia de Buenos Aires) and UNLP (Universidad Nacional de La Plata) for their sponsorship to do this research. The authors also want to thank Colores Hispania for providing the anticorrosive pigment.

\section{REFERENCES}

[1] Meyer, G.- Farbe+Lack, 69 (7), 528 (1963).

[2] Meyer, G.- Farbe+Lack, 71 (2), 113 (1965).

[3] Adrian, G.; Gerhard, A.; Bittner, A; Gawol, M.- European Supplement to Polymer Paint Colour Journal, 62 (1981).

[4] Leidheiser (Jr.), H.- J. Coat. Tech., 53 (678), 29 (1981).

[5] Gerhard, A.; Bittner, A. J. Coat. Tech., 58 (740), 59 (1986).

[6] Bittner, A- J. Coat.Tech., 61 (777), 111 (1989).

[7] Ambrose, J.R.- Corrosion (NACE), 34 (1), 27 (1978).

[8] Szklarska-Smialowska, Z.; Mankowsky, J.- Br. Corros. J., 4 (9), 271 (1969).

[9] Andrade, E.M.; Molina, F.V.; Posadas, D.- J. Colloid and Interface Science, 165, 450 (1994)

[10] Andrade, E.M.; Gordillo, G.J.; Molina, F.V.; Posadas, D.- J. Colloid and Interface Science, 173, 231 (1995)

[11] Andrade, E.M.; Molina, F.V.; Gordillo, G.J.; Posadas, D.- J. Colloid and Interface Science, 165, 459 (1994)

[12] Giúdice, C.; Benitez, J.C.; Rascio, V.- J.Oil Col. Chem Assoc., 62 (3), 151 (1980).

[13] del Amo, B.; Romagnoli, R; Vetere, V.F.- Corrosion Reviews, 14 (1-2), 121-133 (1996).

[14] Payne, H.F.- Organic Coatings Technology, vol II: Pigments and Pigmented Coatings, p.1095, N.Y., Wiley, 1961.

[15] Rascio, V.; Caprari, J.J.; del Amo, B.; Ingeniero, R. JOCCA, 62 (12), 475(1979).

[16] Szauer, T.- Prog. Org. Coatings, 10, 157 (1982). 